\title{
Selection of ports, tariffs, service frequency, and ship size for a SSS Route in Java Island
}

\author{
Johannes E. Simangunsong ${ }^{1, *}$, Ade Sjafruddin², Harun Al-Rasyid S. Lubis ${ }^{2}$, and Russ Bona Frazila ${ }^{2}$ \\ ${ }^{1}$ Doctoral Study Program of Civil Engineering, Institut Teknologi Bandung, Bandung, Indonesia \\ ${ }^{2}$ Transportation Engineering Research Group, Faculty of Civil and Environmental Engineering, Institut Teknologi Bandung, Bandung, \\ Indonesia
}

\begin{abstract}
Short Sea Shipping (SSS) is one of modes to reduce the dominance of trucking mode of freight transportation in Indonesia. It concerns to multimodal freight transportation network system through sea mode transportation line. As a maritime nation, it is possible to develop SSS lines in Indonesia. The development of the SSS lines is expected to improve the continuity of goods which supporting the efficiency and effectiveness of the national logistics system. It develops integrated connectivity in local, inter-island and national scale. The objective of this study is to obtain optimum SSS route with objective function to maximize the difference of total transportation cost by designing SSS operating system model. Several factors are considered in SSS operating system model as policy measures, such as transit ports selection, tariffs, services, and ship sizes. This SSS model is approached by Incremental Assignment method. SSS operating system model will be applied to the freight mobility in Java.
\end{abstract}

\section{Introduction}

Along with the economic development in a region, the freight transportation modes which dominated by truck are limited in serving the freight flow. The freight flow dominated by truck as land mode might cause the traffic issues on roads and ports which impacting high transportation costs. The transportation costs of $12.04 \%$ in Indonesia are the highest component of the average total logistic costs [1]. One of the efforts to improve logistic performance and the domination of land mode is by giving attention to multimodal freight transportation system, which is developing the shipping lines or Short Sea Shipping (SSS) routes.

Multimodal transportation is an effective way to improve the logistics efficiency and the economy in a region. The multimodal transportation combines two or more transportation modes. The objective of the multimodal transportation is to allocate goods from the origin to destination with cheaper transportation costs and shorter travel times [2].

The increase in the facilities and infrastructure capacity for freight transport in Java is currently very necessary. Due to the centralized development in Java, the volume growth of freight transport and motorized vehicles are increasing. Nowadays, freight transport in Java is using 3 modes of transportation, those are trucks, trains, and ships The freight flow in Java Island is dominated by trucks cause traffic congestion, high roads maintenance costs, and and fuel subsidies especially in the
Java northern corridor. Developing other modes, especially in Java, is one of the efforts to improve the performance of freight transportation. Indonesia as maritime nation whose islands are connected by the sea is possible to implement SSS as passangers and freight transportation. One of programs planned to improve the continuity of goods flow in promoting the efficiency and effectiveness of the national logistics system performance is the integrated development of local, inter-island, and national connectivity by developing shipping lines and SSS operational [3]. Several SSS studies on Java Island that have been carried out are Perkasa, L conducted a study on comparative analysis of travel time and SSS tariff with trucks and determined the ship size of the SSS to calculate the tariffs the government must provide to SSS operator in order to operate properly [4]; Wicaksono, $\mathrm{G}$ conducted a research related to Ro-Ro Ship route planning with a combination of Ro-Ro ship and truck tariffs on the northern corridor of Java Island that can maximize the shifting volume of truck to Ro-Ro ship by a concern to the operating costs for Ro ship operators. [5]

\section{Problems of the paper}

Route planning is a combinatorial optimization problem deal with optimal utilization of resource in a system. The performance in the system might be improved efficiently from various point of views (economy, environment, stability, timeliness, etc.) by selecting the optimal route to

\footnotetext{
* Corresponding author: je_mangunsong@yahoo.com
} 
distribute goods flow (i.e. commodities, products data, signals, etc.). Therefore, the optimization of route planning has received much attention not only in transportation sector but also other sectors such as telecommunications, manufacturing system, and internet service networks).

The planning of freight transport routes aims to determine the optimal route to allocate a commodity from origin-destination through transportation network. In design of freight transportation network planning has three levels, that are strategic planning, tactical planning, and operational planning. The freight transport route planning is include in all those three levels and is a shortterm decision making in transportation network design. [3].

The development of a model to select freight transport route due to the implementation of SSS is a fairly complex problems because it involves many actors. The complexity of the model to be built can be seen from number of actions and policies which will be considered in the selection route model. The routing choice model in this study will consider two decision makers concurrently, those are stake holders and network users. Number of policy actions to be selected in this model are the network configuration which related to the transit port location (related strategic planning) and factors related to the the operation SSS attributes, such as tariff, frequency, and capacity of ships (related to operational planning).

Some studies have been conducted related to the planning of SSS route, such as Wong, K. L et al factors that are considered tariff, environmental costs, and fleet costs [6]; Daduna, J. R et.al considered tariff, environmental costs, and travel time costs [7]; Han, M. M and APEC Transportation Working Group and Inha University factors considered are the port capacity and fleet capacity [8,9].

Things that are considered in the studies before are focus only to SSS operational while the network configuration of freight route uses the existing route. Related study about design of multimodal freight transportation network has done before by Russ et.al, who analyzed freight transport network design, particularly in the selection of the most feasible set of infrastructure projects [10]; Yamada et.al conducted a research related to model for strategic transport planning, particularly in freight terminal development and interregional freight transport network design [11]

This study will choose the SSS operational actions and consider the selection of freight network configuration. After several explanations, some of the issues that will be answered in this study are: (1) how is the model of multimodal freight transportation route selection that will be developed can facilitate the interests of stake holders and network users, also maximize the shift of transportation modes from land to sea and (2) what are the set of policies that will be selected to maximize the shift of transportation modes from land to sea.

\section{Objectives}

The study on the effect of the SSS application on the selection of multimodal freight transport route aims to: select the optimum SSS route which is indicated by the highest value of the difference between total transportation costs without SSS and total transportation costs with SSS and select a set of action combinations which related to the SSS operational attributes and the selection of network configuration/scheme so that maximizing the shift of transport mode from land to sea.

\section{Methods}

The route selection model that will be developed in this study uses the first Wardrop principle that is the problem of user equilibrium (UE) which will be solved using Incremental Loading (Incremental Assignment) technique with Matlab. The output of this study is a model that can estimate the equilibrium flow, transportation costs of each link which used to calculate total generalized costs (total transportation costs). This model will be tried on the multimodal freight transport network in Java Island.

\section{Formulation model}

The objective function of the research is to maximize the deviation total transportation cost between without operation and operation the SSS. The total transportation cost due to the operation of the SSS is obtained from the total link flows shifting to the SSS multiplied by the transportation cost. The formulation of the objective function $\mathrm{F}$ is formulated as follows

$F=T_{0}-\left[\sum_{a \in A_{1}} x_{a}^{*} c_{a}\left(x_{a}^{*}\right)+\sum_{a \in A_{2}} x_{a}^{*} c_{a}\left(x_{a}^{*}, y_{a}\right)\right]$

where $T_{o}$ shows total transportation costs on the network without SSS operation:

$$
T_{o}=\sum_{a \in A} x_{o a}^{*} c_{a}\left(x_{o a}^{*}\right)
$$

$x_{o a}$ is the equilibrium link flow at the time SSS not operated, where

$x_{a}^{*} \quad:$ link flows that are the solution for the user equilibrium problem with the set of implemented combination actions

$c_{a}\left(x^{*}{ }_{a}, y_{a}\right)$ : transportation costs on link a at equilibrium flow condition and set of implemented combination actions or not (ya, is indicator of combination action which has binary value 1 if it is implemented and 0 if it is not)

$A_{1} \quad$ : set of existing link without implementedaction

$A_{2} \quad$ : set of existing link which allow the implemented-action

The mechanism of assignment problem of freight in network is formulated in the mathematical model, in example let $\mathrm{p}$ as the path and $\mathrm{P} \omega$ as the set of all paths in the network connecting origin-destination (OD) pair $\omega$, 
where all (OD) pairs belong to the set of $\Omega$. Furthermore, fp $\omega$ can be defined as the flow on path p connecting $\omega$, and xa is defined as the flow at link a. The following is links flow formulation $[10,11]$ :

$$
x_{a}=\sum_{\omega \in \Omega} \sum_{p \in P \omega} f_{p w} \delta_{a p w}, \quad \forall a \in A
$$

Where:

$$
\delta_{\text {apw }}= \begin{cases}1, & \text { if path } p \text { connecting } \omega \text { using links a } \\ 0, & \text { otherwise }\end{cases}
$$

Furthermore, the conservation of flow between (OD) pair $\omega$ in the non-negative path flow can be expressed as:

$$
\begin{gathered}
q_{\omega}=\sum_{p \in P \omega} f_{p \omega}, \forall \omega \in \Omega \\
f_{p \omega} \geq 0
\end{gathered}
$$

Where $\mathrm{q} \omega$ as the travel demand related to pair OD $\omega$ The assignment problem of user equilibrium (EU) flow above will be solved by using theequation below: Determine $x_{a}$ so every path has the equal and minimum transportation costs.

$$
\operatorname{Minimasi} Z\left(x_{a}\right)=\sum_{a \in A} \int_{0}^{x_{a}} C_{a}\left(x_{a}\right) d\left(x_{a}\right)
$$

With constrains :

$$
\begin{gathered}
x_{a}=\sum_{\omega \in \Omega} \sum_{p \in P \omega} f_{p w} \delta_{a p w}, \quad \forall a \in A \\
q_{\omega}=\sum_{p \in P \omega} f_{p w}, \forall \omega \in \Omega \\
f_{p \omega} \geq 0
\end{gathered}
$$

\section{Transportation model}

\subsection{Zones}

A zone in this SSS route optimization model is the origin and destination point of goods flow. In this study, zoning division was based on the administrative borderline of district/city, geography of the region, and district/city status as the center of activities. There are 55 center of zones which will represent all districts and cities that are located throughout Java.

\subsection{Nodes}

The node in this study represents centers of activity of a district/city or transfer points such as terminals, stations,

\begin{tabular}{|c|c|c|c|}
\hline $\begin{array}{c}\text { No. } \\
\text { Zona }\end{array}$ & $\begin{array}{l}\text { Center of } \\
\text { Zona }\end{array}$ & $\begin{array}{c}\text { No. } \\
\text { Zona }\end{array}$ & $\begin{array}{l}\text { Center of } \\
\text { Zona }\end{array}$ \\
\hline 4 & Probolinggo & 32 & Wonosobo \\
\hline 5 & Lumajang & 33 & Kebumen \\
\hline 6 & Pasuruan & 34 & Pekalongan \\
\hline 7 & Malang & 35 & Purwekerto \\
\hline 8 & Surabaya & 36 & Cilacap \\
\hline 9 & Lamongan & 37 & Tegal \\
\hline 10 & Blitar & 38 & Banjar \\
\hline 11 & Kediri & 39 & Cirebon \\
\hline 12 & Jombang & 40 & Kuningan \\
\hline 13 & Tuban & 41 & Tasikmalaya \\
\hline 14 & Bojonegoro & 42 & Indramayu \\
\hline 15 & Trenggalek & 43 & Sumedang \\
\hline 16 & Madiun & 44 & Bandung \\
\hline 17 & Pacitan & 45 & Purwakarta \\
\hline 18 & Pamengkasan & 46 & Karawang \\
\hline 19 & Jogja & 47 & Bekasi \\
\hline 20 & Gn Kidul & 48 & Cianjur \\
\hline 21 & Kulon Progo & 49 & Sukabumi \\
\hline 22 & Rembang & 50 & Bogor \\
\hline 23 & Kudus & 51 & DKI \\
\hline 24 & Semarang & 52 & Pandeglang \\
\hline 25 & Salatiga & 53 & Tangerang \\
\hline 26 & Boyolali & 54 & Serang \\
\hline 27 & Surakarta & 55 & Cilegon \\
\hline 28 & Sragen & & \\
\hline
\end{tabular}
ports, airports or intersections connected by the road network, rail network and sea network. In this study, the most important node is the port node because it is the node that will be selected so it can provide an optimum SSS operating system.

Tabel 1. Zone for Zoning System in Java Island

\begin{tabular}{|c|l|c|l|}
\hline $\begin{array}{c}\text { No. } \\
\text { Zona }\end{array}$ & $\begin{array}{c}\text { Center of } \\
\text { Zona }\end{array}$ & $\begin{array}{c}\text { No. } \\
\text { Zona }\end{array}$ & $\begin{array}{c}\text { Center of } \\
\text { Zona }\end{array}$ \\
\hline 1 & Banyuwangi & 29 & Klaten \\
\hline 2 & Situbondo & 30 & Magelang \\
\hline 3 & Jember & 31 & Kendal \\
\hline
\end{tabular}

\subsection{Transfer Points}

The transfer point is the location where intermodal transfer of the freight can occur. In this study, the transfer point is found in ports and stations that represent the transfer of goods between different modes. This transfer point is assumed to be dummy link. Table 2 as follow shows the list of modeled ports and stations

Table 2. List of modeled ports and stations

\begin{tabular}{|c|l|l|l|}
\hline No. & $\begin{array}{c}\text { Centre of } \\
\text { Zones }\end{array}$ & \multicolumn{1}{|c|}{ Ports } & \multicolumn{1}{|c|}{ Stations } \\
\hline 1 & DKI Jakarta & Tanjung Priuk & Gambir \\
\hline 2 & Cirebon & Cirebon & Cirebon \\
\hline & Banten & Bojonagara & Serang \\
\hline 3 & Semarang & Tanjung Emas & Semarang \\
\hline 4 & Surabaya & Tanjung Perak & Gubeng \\
\hline 5 & Cikampek & & Cikampek \\
\hline 6 & Bandung & & Bandung \\
\hline 7 & Cilacap & & Cilacap \\
\hline 8 & Solo & & Balapan Solo \\
\hline
\end{tabular}

\subsection{Links}

In this study, links is a form of infrastructure network that is divided according to the modeled transportation modes. This link connects two nodes with the transport network according to the represented mode. The modeled road network infrastructure is national roads and highway roads. The modeled road infrastructure network is 
presented in Figure 1. The railroad infrastructure network in Java is shown in Figure 2.

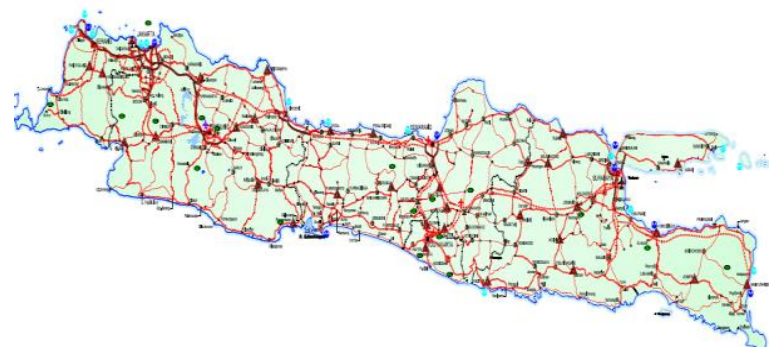

Fig. 1. The modeled roads infrastructure network in Java

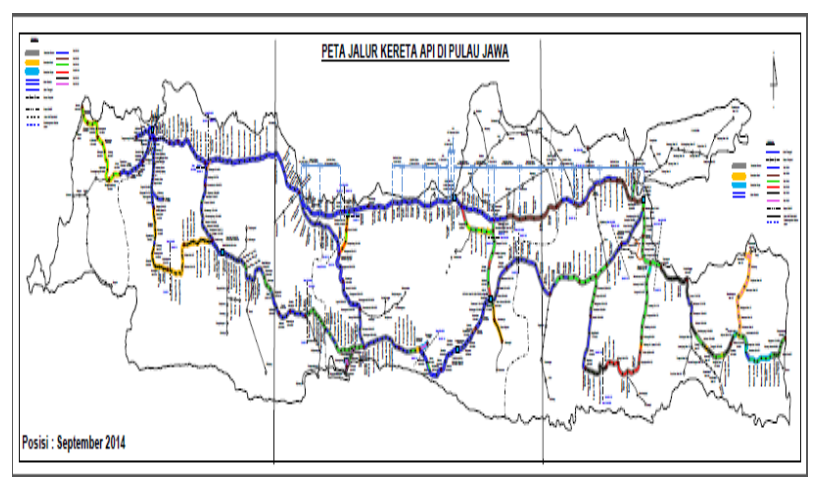

Fig. 2. The modeled railroads infrastructure network in Java

\subsection{The origin-destination matrix}

The origin-destination matrix for the goods transportation was obtained from the Origin Destination Matrix per city/regency in 2011. The movement of goods using land mode was assumed based on State Logistic Indonesia in 2013 which stated that $76 \%$ of goods movement in Indonesia uses land mode. The origin destination matrix in this model was calculated in units of container trucks per week where 1 truck is assumed to have a load of 10 tons. (equivalent to 1 TEUS $20 \mathrm{ft}$ )

\subsection{Transportation modes and infrastructure}

The considered mode in this study is land modes, those are truck and train modes, also sea mode, Ro-Ro ship. In this study, there were three modeled transportation network infrastructures, those are road network infrastructure, railroad network infrastructure and sea infrastructure for short sea shipping. Table 3 below explains the modes and transportation infrastructure modeled in this study

Table 3. Modes and transportation infrastructure modeled in this study

\begin{tabular}{|l|l|l|}
\hline No. & Description & Notes \\
\hline 1 & Truck mode & $\begin{array}{l}\text { Land vehicles such as trucks or } \\
\text { trailers with the ability to carry } \\
10 \text { tons (equivalent to 1 TEU) }\end{array}$ \\
\hline 2 & $\begin{array}{l}\text { Railway } \\
\text { mode }\end{array}$ & $\begin{array}{l}\text { Railway transport with an } \\
\text { average load of 20 tons with total } \\
\text { average of 20 transported } \\
\text { carriages }\end{array}$ \\
\hline
\end{tabular}

\begin{tabular}{|l|l|l|}
\hline No. & Description & Notes \\
\hline 3 & Ro-Ro Ship & $\begin{array}{l}\text { Goods transport using sea } \\
\text { transportation with Ro-Ro Ship }\end{array}$ \\
\hline 4 & $\begin{array}{l}\text { National } \\
\text { roads }\end{array}$ & $\begin{array}{l}\text { Road infrastructure used for } \\
\text { goods movement in truck mode }\end{array}$ \\
\hline 5 & Toll roads & $\begin{array}{l}\text { Paid road infrastructure used for } \\
\text { the goods movement in truck } \\
\text { mode }\end{array}$ \\
\hline 6 & Railway line & $\begin{array}{l}\text { Railway line used for the } \\
\text { movement goods by rail mode }\end{array}$ \\
\hline 7 & $\begin{array}{l}\text { Shipping } \\
\text { tline }\end{array}$ & $\begin{array}{l}\text { Shipping line used for the } \\
\text { movement of goods by Ro-Ro } \\
\text { Ship }\end{array}$ \\
\hline 8 & Ro-Ro port & $\begin{array}{l}\text { Infrastructure where goods flow } \\
\text { from truck to sea modet }\end{array}$ \\
\hline 9 & $\begin{array}{l}\text { Railway } \\
\text { station }\end{array}$ & $\begin{array}{l}\text { Infrastructure where goods move } \\
\text { from truck mode to rail mode }\end{array}$ \\
\hline
\end{tabular}

\section{Cost function}

Transportation cost unit described as cost function on link, link transfer, and value of travel time of the commodity described using the following equation [10]

$$
c_{a}\left(x_{a}\right)=\alpha_{a}+\beta t_{a}\left(x_{a}\right)
$$

Where :

$$
\begin{array}{ll}
\mathrm{c}_{\mathrm{a}}\left(\mathrm{x}_{\mathrm{a}}\right) & =\text { transportation cost on link a (Rp) } \\
\alpha_{a} & =\text { tariff on link a (Rp) } \\
\beta & =\text { time value }(\mathrm{Rp} / \text { hour }) \\
t_{a}\left(x_{a}\right) & =\text { time spent on link a (hour) } \\
x_{a} & =\text { flow on link a (veh) }
\end{array}
$$

Transferring to a node describes loading-unloading process:

For truck volume $\leq$ the capacity of the ship or train the time travel on transfer link a is

$$
t_{a}=\left(\left(\frac{h}{2}+r\right) \times \beta\right)
$$

While for truck volume $\geq$ the capacity of the ship or train the time travel on transfer link a is

$$
t_{a}=\left(\left(\frac{h}{2} \times\left(\frac{x_{a}}{k}+1\right)+r\right) \times \beta\right)
$$

Where :

$h=$ headway in ports or stations (hour)

$t_{o}=$ time spent on transfer link $a$ (hour)

$\mathrm{r}=$ loading-unloading time (hour)

$x_{a}=$ total flow loading-unloading (veh)

$k=$ capacity on transfer link (veh)

$\beta=$ time value (Rp/hour)

\section{Case study: selection of optimum sss route in Java}

There are 2 things directly answered in this model simultaneously due to the application of SSS route in 
Java. First, it selects the scenario combination set giving optimum objective function while second, it selects the optimum SSS route.

Several sets of scenarios that will be implemented to obtain the optimum SSS route on Java are:

1. Selecting 5 ports stops to load and unload freight transport, those are:

- $\quad$ Bojonagara Port (P1)

- Tanjung Priok Port (P2)

- Cirebon Port (P3)

- $\quad$ Tanjung Mas Port (P4)

- Tanjung Perak Port (P5)

2. Selecting SSS operation tariff from 2 types of tariff on link or specified SSS segment, those are:

- $\quad$ Normal Tariff (T1)

- $10 \%$ of tariff reduction from normal (T2)

3. Selecting the frequency SSS operational service from 2 type frequencies, such as:

- 1 ship/week (F1)

- 2 ships/week (F2)

4. Selecting the size of ship used for SSS operation from 2 types of ship size specified, those are:

- Ship with capacity of 100 truck (K1)

- Ship with capacity of 200 truck (K2)

Based on the set of scenarios above, there are 26 SSS routes shown by the combination of port configuration. Through the assignment problem approach, each route and operating system was calculated and analyzed. All the SSS route combinations and the difference of total cost due to the implementation of SSS route are fully presented in Table 4. The difference of total transportation cost in the table below was obtained by applying Tariff I (T1), frequency 1 ship per week (F1), and type of ship size with the capacity of 100 trucks (K1).

Based on the combination of ports shown in Table 4, the optimum routes are the port of Cirebon (P3) and the port of Tanjung Perak (P5). The optimum SSS route in Java resulted in reduction of total transportation costs of Rp 1.512.881.984,-. The simulation on that route by applying Tariff II, (T2), frequency 2 ship per week (F2), and type of ship size with the capacity of 200 trucks (K2) was done after the optimum SSS route obtained. The simulation on optimum SSS route results the reduction of total transportation cost by Rp 1.608.378.479,-.

Table 4 shows the combination of ports no. 10 and 16 results in equally total transportation cost. Based on loading analysis, the P1-P3 route does not result in the shift of truck mode to SSS mode. The shift occurs only on P2-P3 routes. This result shows the weaknesses of the model built in this study. For further study, SSS operational costs must be considered into the model so the problems mentioned above can be avoided. In addition, considering the SSS operating costs in the model gives the effectiveness or benefits of operating the SSS, so it might be discovered whether this operation provides benefits for logistical problems in Java.

In this study, SSS operating costs have not been considered in the model, so the effectiveness or benefits of the operation of SSS are not clear. For further research, it is necessary to consider the costs incurred to operate
SSS on Java, as the information whether the initial operation can provide benefits value for logistical problems in Java.

Table 4. SSS route combination by applying T1, F1, and K1

\begin{tabular}{|c|c|c|}
\hline No & $\begin{array}{l}\text { Combination of } \\
\text { Ports }\end{array}$ & $\begin{array}{c}\text { The Difference of } \\
\text { Total Transportation } \\
\text { Cost (Rp) }\end{array}$ \\
\hline 1 & - & 0 \\
\hline 2 & P1-P2 & 0 \\
\hline 3 & P1-P3 & 0 \\
\hline 4 & P1-P4 & 0 \\
\hline 5 & $\mathrm{P} 1-\mathrm{P} 5$ & 0 \\
\hline 6 & $\mathrm{P} 2-\mathrm{P} 3$ & $625,184,038$ \\
\hline 7 & P2-P4 & 0 \\
\hline 8 & $\mathrm{P} 2-\mathrm{P} 5$ & 0 \\
\hline 9 & P3-P4 & $642,922,950$ \\
\hline 10 & P3-P5 & $1,512,881,984$ \\
\hline 11 & P4-P5 & $555,071,187$ \\
\hline 12 & P1-P2-P3 & $625,184,038$ \\
\hline 13 & P1-P2-P4 & 0 \\
\hline 14 & P1-P2-P5 & 0 \\
\hline 15 & P1-P3-P4 & $642,922,950$ \\
\hline 16 & P1-P3-P5 & $1,512,881,984$ \\
\hline 17 & P1-P4-P5 & $555,071,187$ \\
\hline 18 & P2-P3-P4 & $625,184,038$ \\
\hline 19 & P2-P3-P5 & $780,949,255$ \\
\hline 20 & P2-P4-P5 & $555,071,187$ \\
\hline 21 & P3-P4-P5 & $555,071,187$ \\
\hline 22 & P1-P2-P3-P4 & $625,184,038$ \\
\hline 23 & P1-P2-P3-P5 & $780,949,255$ \\
\hline 24 & P1-P3-P4-P5 & $555,071,187$ \\
\hline 25 & P2-P3-P4-P5 & $590,088,479$ \\
\hline 26 & P1-P2-P3-P4-P5 & $590,088,479$ \\
\hline
\end{tabular}

This research is supported by P3MI ITB research program, Faculty of Civil and Environmental Engineering, Bandung Institute of Technology

\section{References}

1. Centre of Logistics and Supply Chain Studies ITB, State of Logistics Indonesia (2013)

2. M. SteadieSeifi, N.P. Dellaert, N.T.V. Woensel, dan R.Raofi, Multimodal Freight Transportation Planning: A Literature Review, European Journal of Operational Research, Vol. 233, pp 1 - 15 (2014)

3. Indonesian Government Regulation No. 26 of 2012 
4. L. Perkasa, Study of Short Sea Shipping Activities in Northern Java Island, Thesis, Post Graduate School Programmes Bandung Institute of Technology (2014)

5. G. Wicaksono, The Planning of Ro-Ro Ship Routes on the North Java Island Corridor, Thesis, Post Graduate School Programmes Bandung Institute of Technology (2015).

6. K.I. Wong, P.T.W. Lee, W.Y. Szeto, dan G.H. Lai, A multimodal Network Design Problem for Domestic Container Transportation with Short Sea Shipping, The 12th World Conference on Transport Research (WCTR), Lisbon, Portugal (2010)

7. J. R. Daduna, K. Hunke, Prause, Analysis of Short Sea Shipping-Based Logistics Corridors in the Baltic Sea Region, Journal of Shipping and Ocean Engineering 2, pp. 304-319 (2012)

8. M.M. Han, L. Guolong, dan Y. Bin, A Linear Programming Model For Short Sea Shipping And Multimodal Inland Transportation In Myanmar, Report and Opinion, 3(1) (2011)

9. APEC Transportation Working Group and Inha University, Short Sea Shipping Studi: A Report on Successful SSS Models That Can Improve Ports Efficiency and Security while Reducing Congestion, Fuel Cost, and Pollution. Asia-Pasific Economic Cooperation (2007)

10. B.F. Russ, J. Castro, T. Yamada, H. Yasukawa, Optimising The Design of Multimodal Freight Transport Network in Indonesia, Journal of Eastern Asia Society for Transportation Studies, Vol. 6, pp. 2894-2907 (2005)

11. T. Yamada, R.B. Frazila, J. Castro, dan E. Taniguchi, Designing Multimodal Freight Transport Networks: A heuristic Approach and Applications, Transportation Science Journal, Vol. 43, pp 129-143 (2009) 